\title{
Checklist of ectoparasites of Canidae and Felidae in Mexico
}

\author{
Jessica E. Light*, Ralph P. Eckerlin², Lance A. Durden ${ }^{3}$ \\ 'Department of Wildlife and Fisheries Sciences, Texas A\&M University, College Station, 77843. Texas, United States. Email: jlight2@ \\ tamu.edu (JEL). \\ ${ }^{2}$ Natural Sciences Division, Northern Virginia Community College, Annandale, 22003. Virginia, United States. Email: reckerlin@ \\ nvcc.edu (RPE). \\ ${ }^{3}$ Department of Biology, Georgia Southern University, Statesboro, 30458. Georgia, United States. Email:Idurden@georgiasouthern. \\ edu (LAD).
}

We report an updated checklist of ectoparasites associated with canid and felid species in Mexico. We provide taxonomic authority, specific host associations, collection localities with appropriate citations from the literature, and museum collection information, when available. A total of 31 tick, 4 mite, 18 flea, and 4 louse species are reported from 10 host species (4 canids and 6 felids) across 29 states in Mexico.

Reportamos una lista anotada actualizada de las especies de ectoparásitos de cánidos y felinos en México. Proveemos la autoridad taxonómica, las asociaciones específicas, localidades de recolecta y referencias; así como la información de museos y colecciones, cuando estan disponibles. Un total de 31 especies de garrapatas, 4 de ácaros, 18 pulgas y 4 de piojos se reportan de 10 hospederos (4 cánidos y 6 felinos) en 29 estados de México.

Key Words: Acari; Canidae; Felidae; flea; Ixodida; louse; Mexico; mite; Phthiraptera; Siphonaptera; tick.

(C) 2019 Asociación Mexicana de Mastozoología, www.mastozoologiamexicana.org

\section{Introduction}

Mammals belonging the carnivore families Canidae (dogs and their relatives) and Felidae (cats and their relatives) are relatively well known due to their large size and charismatic nature. Worldwide, 39 canid and 42 felid species are currently recognized (Burgin et al. 2018); however, the number in Mexico is much smaller at approximately 8 and 6 species, respectively. The ectoparasite fauna (e. g., ticks, mites, fleas, and lice) of these animals has been characterized in the past in separate species descriptions and checklists. For example, Cooley and Kohls (1945), Kohls and Clifford (1966), and Guzmán-Cornejo et al. (2007a, 2007b) are excellent references for ticks and Sánchez-Montes et al. (2018) is a thorough review of Mexican chewing lice. Hopkins and Rothschild (1966), Barnes et al. (1977), Muñiz et al. (1981), Ayala-Barajas et al. (1988), Morales-Muciño and LlorenteBousquets (1985), Morales and Llorente (1986), Ponce and Llorente (1996), and Acosta et al. (2008) are just a few of the outstanding references for fleas in Mexico and nationwide. Lastly, Whitaker and Morales-Malacara (2005) present a comprehensive list of mammal-ectoparasite associations in Mexico, with references to the original literature.

Here, we present a checklist summarizing all major ectoparasite groups from canid and felid species across Mexico. We consolidated information from previously published checklists and searched for new host-parasite records in Web of Science using the following search terms: felid*/ canid* AND flea*/tick*/mite*/louse/lice AND Mexico. We also searched for each canid and felid genus known from Mexico with the same parasite search terms above. For each ectoparasite species, we provide taxonomic authority, host associations, collection localities and references, and museum collection information (sometimes with collec- tion number), when available. Some parasite-records are newly reported here after examination of specimens of the U. S. National Tick Collection, Georgia Southern University, Statesboro. Parasite species listed as "sp." from different localities, host species, or publications may represent different species. All localities listed below are taken directly from the literature or specimen slides. Locality clarifications, if necessary, are listed in brackets following the relevant locality. Collection acronyms are as follows: $\mathrm{BMNH}=$ Department of Entomology, The Natural History Museum, London, England; CAIM, InDRE = Colección de Artrópodos con Importancia Médica from Instituto de Diagnóstico y Referencia Epidemiológicos de la Secretaría de Salud, Mexico City; $\mathrm{CMNH}=$ Carnegie Museum of Natural History (Traub collection); CNAC = Colección Nacional de Ácaros, Instituto de Biología, Universidad Nacional Autónoma de México; MZFC, SIPHO = Colección de Siphonaptera at the Museo de Zoología Alfonso L. Herrera, Universidad Nacional Autónoma de México, Mexico City, Distrito Federal; NTC $=$ L.G. Neumann Tick Collection, École Nationale Vétérinaire, Toulouse, France; USNTC = U. S. National Tick Collection, Georgia Southern University, Statesboro.

We document a total of approximately 31 tick, 4 mite, 18 flea, and 4 louse species from 10 host species (4 canids and 6 felids) across 29 states from Mexico. These numbers are almost certainly an underestimate, especially given that ectoparasites are only recorded from half of the known Mexican canid species and that several of the ectoparasite taxa listed below could not be identified to species. However, we note that ectoparasite contamination commonly occurs among host species when specimens are not processed carefully. Thus, readers of any checklist should be wary of the potential of incorrect information resulting 
from contamination. We encourage researchers to carefully process host specimens and publish their findings of both presence and absence of ectoparasites from canid and felid species. We also strongly recommend researchers to deposit ectoparasite specimens in natural history museums. Researchers working with canid and felid species should take all available data from host specimens in the field, including their parasites (e.g., a "holistic" or "extended" specimen; Cook et al. 2016, 2017; Webster 2017; Cook and Light 2019). Holistic specimens will provide much needed data about parasite fauna and distribution of those fauna such that subsequent studies can be conducted. Lastly, our search of the U. S. National Tick Collection at Georgia Southern University alone resulted in a minimum of 1 previously undescribed host-parasite association, 8 new state records, and 5 parasite associations with a novel host. Thus, future checklists should explore holdings in natural history collections which may result in additional host-parasite associations and locality records.

\section{Phylum: Arthropoda von Siebold, 1848 \\ Class: Arachnida Lamarck, 1801 \\ Subclass: Acari Leach, 1817 \\ Superorder: Parasitiformes Leach, 1815 \\ Order: Ixodida Leach, 1815}

Family: Argasidae Koch, 1844

Ornithodoros nicollei Mooser, 1932

PUEBLA: Canis lupus familiaris (Davis 1943, Hoffmann 1962). Specimens in collections: Unknown; Hoffmann collection is in the CNAC.

\section{Otobius megnini (Dugès, 1884)}

CIUDAD DE MÉXICO: Gregorio: Canis lupus familiaris (USNTC). Specimens in collections: USNTC (RML23442). Castillo de Chapultepec; Los Morales; Tacuba: C. I. familiaris. Azcapotzalco: Felis catus (Hoffmann 1962). Specimens in collections: Unknown; Hoffmann collection is in the CNAC. SINALOA: El Fuerte: C. I. familiaris (Hoffmann 1962). Specimens in collections: Unknown; Hoffmann collection is in the CNAC.

Ixodidae Koch, 1844

Amblyomma americanum Linnaeus, 1758

TAMAULIPAS: Naranjo: Canis lupus familiaris (USNTC). Specimens in collections: USNTC (RML21774). NOT DETERMINED: C. I. familiaris (Chavarría 1941, Hoffmann 1961, Hoffmann 1962, Hoffmann and López-Campos 2000, GuzmánCornejo et al. 2011). Specimens in collections: Unknown; Hoffmann collection is in the CNAC.

\section{Amblyomma auricularium (Conil, 1878)}

YUCATÁN: Tekom: Leopardus pardalis (USNTC). Specimens in collections: USNTC (RML32132). Ticul [listed as
Ticul Municipio in the literature]: Canis lupus familiaris (Rodríguez-Vivas et al. 2016). No specimens in collections.

\section{Amblyomma inornatum (Banks, 1909)}

OAXACA: Santa Catalina de Sena, Tlalixtac de Cabrera [locality from the literature:"Santa Catarina de Sena"]: Canis lupus familiaris (Guzmán-Cornejo et al. 2011). Specimens in collections: CNAC.

\section{Amblyomma maculatum Koch, 1844}

CHIAPAS: Urocyon cinereoargenteus (Hoffmann et al. 1972, Hoffmann and López-Campos 2000, Whitaker and Morales-Malacara 2005, Guzmán-Cornejo et al. 2011). Specimens in collections: Unknown; Hoffmann collection is in the CNAC. SINALOA: Canis lupus familiaris (Hoffmann 1925, Tovar 1944, Hoffmann 1962, Hoffmann and LópezCampos 2000, Guzmán-Cornejo et al. 2011). Specimens in collections: Unknown; Hoffmann collection is in the CNAC. Culiacán: C. I. familiaris (USNTC). Specimens in collections: USNTC (RML21199). TABASCO: Río Playa, Comalcalco: C. I. familiaris (Guzmán-Cornejo et al. 2011). Specimens in collections: CNAC. YUCATÁN: Ticul [listed as Ticul Municipio in the literature]: C. I. familiaris (Rodríguez-Vivas et al. 2016). No specimens in collections.

\section{Amblyomma mixtum (Koch, 1844)}

CHIAPAS: Ciudad [San Cristóbal de] Las Casas; Tapachula: Canis lupus familiaris (Hoffmann 1962, GuzmánCornejo et al. 2011). Urocyon cinereoargenteus (Hoffmann et al. 1972, Hoffmann and López-Campos 2000, GuzmánCornejo et al. 2011). Specimens in collections: Unknown; Hoffmann collection is in the CNAC. CIUDAD DE MÉXICO: C. I. familiaris (Guzmán-Cornejo et al. 2011). Specimens in collections: CNAC. DURANGO: Maguey Citas: Felis catus (USNTC). Specimens in collections: USNTC (RML124465). NUEVO LEÓN: Santiago; Guadalupe: C. I. familiaris (Galaviz-Silva et al. 2013). No specimens in collections. OAXACA: Ixtepec: C. I. familiaris (USNTC). Specimens in collections: USNTC (RML21198). Salina Cruz: C. I. familiaris (Hoffmann 1962). Specimens in collections: Unknown; Hoffmann collection is in the CNAC. SAN LUIS POTOSÍ: Los Sabinos; Rancho del Charro; Tamazunchale; [Ciudad] Valles; Xilitla: C. I. familiaris (Hoffmann 1962). Specimens in collections: Unknown; Hoffmann collection is in the CNAC. TABASCO: Finca Cholula: C. I. familiaris (GuzmánCornejo et al. 2011). Specimens in collections: CNAC. TAMAULIPAS: San Jose: C. latrans (USNTC). Specimens in collections: USNTC (RML15899). Reserva de Biosfera de El Cielo: Panthera onca (Almazán et al. 2013). Tampico: C. I. familiaris (Roberts 1934, Guzmán-Cornejo et al. 2011). C. I. familiaris (Gordillo-Pérez et al. 2009, Guzmán-Cornejo et al. 2011). No specimens in collections. VERACRUZ: Tampico: C. I. familiaris (USNTC). Specimens in collections: USNTC (RML25330). Cosamaloapan; Tres Valles; 
Tuxtla [San Andrés]: C. I. familiaris (Hoffmann 1961, Hoffmann 1962, Guzmán-Cornejo et al. 2011). Specimens in collections: Unknown; Hoffmann collection is in the CNAC. YUCATÁN: Hunucma, Teabo, Tetiz, Tizimin, Izamal, Maxcanu, Rio Lagartos [listed as "communities" in the literature]: C. I. familiaris (Zavala-Velázquez et al. 2002, Guzmán-Cornejo et al. 2011). Mayapan [listed as Municipio in the literature]: C. I. familiaris (Peniche-Lara et al. 2018). Tizimin, Muna, Valladolid, and Ticul [listed as Municipios in the literature]: C. I. familiaris (Rodríguez-Vivas et al. 2016). No specimens in collections. UNKNOWN LOCALITY: Leopardus pardalis (Hoffmann 1962, Whitaker and Morales-Malacara 2005). Specimens in collections: Unknown; Hoffmann collection is in the CNAC. Note: This tick species was previously recognized in the literature as A. cajennese (Fabricius, 1787). However, there have been recent updates to taxonomy by Beati et al. (2013) and Nava et al. (2014b) such that the species in this complex that occurs in Mexico is A. mixtum.

Amblyomma oblongoguttatum Koch, 1844

OAXACA: Jagalaxi: Canis lupus familiaris (USNTC). Specimens in collections: USNTC (RML28410, 28412).

\section{Amblyomma ovale Koch, 1844}

CHIAPAS: Canis lupus familiaris (Hoffmann 1961, Hoffmann 1962, Hoffmann and López-Campos 2000, GuzmánCornejo et al. 2011). $6.5 \mathrm{~km}$ del Crucero Frontera, Frontera Corozal: Urocyon cinereoargenteus (Guzmán-Cornejo et al. 2011). Specimens in collections: CNAC. OAXACA: Jagalaxi: C. I. familiaris. San Antonio Otate: C. I. familiaris (USNTC). Specimens in collections: USNTC (RML28410, 28411, 28412). PUEBLA: Zoquipan: C. I. familiaris (USNTC). Specimens in collections: USNTC (RML21704). Ahuaxintila, "onza real" (this may correspond to Herpailurus yaguaroundi; Guzmán-Cornejo et al. 2011). Specimens in collections: CNAC. TABASCO: Huixtla: C. I. familiaris (Hoffmann 1961, Hoffmann 1962, Hoffmann and López-Campos 2000, Guzmán-Cornejo et al. 2011). Specimens in collections: Unknown; Hoffmann collection is in the CNAC. VERACRUZ: Cotaxla: C. I. familiaris (Hoffmann 1962, Hoffmann and López-Campos 2000, Guzmán-Cornejo et al. 2011). Specimens in collections: Unknown; Hoffmann collection is in the CNAC. YUCATÁN: Ticul [listed as Municipio in the literature]: C. I. familiaris (Rodríguez-Vivas et al. 2016). No specimens in collections.

\section{Amblyomma parvum Aragão, 1908}

GUERRERO: Panthera onca (Hoffmann 1962, Hoffmann and López-Campos 2000, Whitaker and Morales-Malacara 2005, Guzmán-Cornejo et al. 2011). Specimens in collections: CNAC. Note: Alternative potential host is Herpailurus yaguaroundi. YUCATÁN: Valladolid [listed as Municipio in the literature]: Canis lupus familiaris (Rodríguez-Vivas et al.
2016). Merida [listed as Municipio in the literature]: Felis catus (Rodríguez-Vivas et al. 2016). No specimens in collections.

Amblyomma sabanerae Stoll, 1894

YUCATÁN: Peto [listed as Municipio in the literature]: Canis lupus familiaris (Rodríguez-Vivas et al. 2016). No specimens in collections.

\section{Amblyomma tennellum Koch, 1844}

SAN LUIS POTOSÍ: Los Sabinos: Canis lupus familiaris (Guzmán-Cornejo et al. 2011). Specimens in collections: CNAC. Note: This tick species was previously recognized in the literature at $A$. imitator Kohls, 1958 , but that name was shown to be a junior synonym of $A$. tennellum Koch, 1844 by Nava et al. (2014a). Amblyomma sp. (immature specimens that could not be identified to species). OAXACA: Jagalaxi: C. I. familiaris (USNTC). SINALOA: La Labor: C. I. familiaris (USNTC). YUCATÁN: Tekom: C. I. familiaris, Leopardus pardalis (USNTC). Specimens in collections: USNTC (RML14005, 28410, 32131, 32132).

\section{Dermacentor andersoni Stiles, 1908}

SINALOA: Canis lupus familiaris (Sosa-Gutiérrez et al. 2016b). No specimens in collections.

\section{Dermacentor dissimilis Cooley, 1947}

SINALOA: Ocolomé: Canis lupus familiaris (GuzmánCornejo et al. 2016). Specimens in collections: CNAC 002077.

\section{Dermacentor halli Mclntosh, 1931}

CHIAPAS: Ciudad [San Cristóbal de] Las Casas: Canis lupus familiaris (Hoffmann 1962, Hoffmann and LópezCampos 2000, Guzmán-Cornejo et al. 2016). Specimens in collections: Unknown; Hoffmann collection is in the CNAC.

\section{Dermacentor nitens Neumann, 1897}

CHIAPAS: Canis lupus familiaris (Hoffmann 1961, GuzmánCornejo et al. 2016). Specimens in collections: Unknown; Hoffmann collection is in the CNAC. COLIMA: C. I. familiaris (Hoffmann 1961, Guzmán-Cornejo et al.2016). Specimens in collections: Unknown; Hoffmann collection is in the CNAC. DURANGO: C. I. familiaris (Hoffmann 1961, Guzmán-Cornejo et al. 2016). Specimens in collections: Unknown; Hoffmann collection is in the CNAC. GUERRERO: C. I. familiaris (Hoffmann 1961, Guzmán-Cornejo et al. 2016). Specimens in collections: Unknown; Hoffmann collection is in the CNAC. HIDALGO: C. I. familiaris (Hoffmann 1961, Guzmán-Cornejo et al. 2016). Specimens in collections: Unknown; Hoffmann collection is in the CNAC. MICHOACÁN: C. I. familiaris (Hoffmann 1961, Guzmán-Cornejo et al. 2016). Specimens in collections: Unknown; Hoffmann collection is in the CNAC. 
OAXACA: C. I. familiaris (Hoffmann 1961, Guzmán-Cornejo et al. 2016). Specimens in collections: Unknown; Hoffmann collection is in the CNAC. PUEBLA: C. I. familiaris (Hoffmann 1961, Guzmán-Cornejo et al. 2016). Specimens in collections: Unknown; Hoffmann collection is in the CNAC. SAN LUIS POTOSÍ: C. I. familiaris (Hoffmann 1961, GuzmánCornejo et al. 2016). Specimens in collections: Unknown; Hoffmann collection is in the CNAC. SINALOA: Ocolomé, C. I. familiaris (Guzmán-Cornejo et al. 2016). Specimens in collections: CNAC 002080. VERACRUZ: Cosamaloapan: C. I. familiaris (Hoffmann 1961, Hoffmann 1962, Guzmán-Cornejo et al. 2016). Specimens in collections: CNAC 002082. YUCATÁN: C. I. familiaris (Hoffmann 1961, Hoffmann 1962, GuzmánCornejo et al. 2016). Specimens in collections: Unknown; Hoffmann collection is in the CNAC. Tizimin [listed as Municipio in the literature]: C. I. familiaris (Rodríguez-Vivas et al. 2016). No specimens in collections.

\section{Dermacentor variabilis (Say, 1821)}

COAHUILA: 10 miles east of Hacienda La Mariposa: Canis latrans (USNTC). Specimens in collections: USNTC (RML32929). NUEVO LEÓN: Pesquería; Benito Juárez; Apodaca; Estanzuela; Guadalupe; Escobedo: C. lupus familiaris (Galaviz-Silva et al. 2013, Guzmán-Cornejo et al. 2016). No specimens in collections. SINALOA: C. I. familiaris (SosaGutiérrez et al. 2016a). No specimens in collections. TAMAULIPAS: Los Tres García, Reynosa: C. I. familiaris (GuzmánCornejo et al. 2016). Matamoros: Lynx rufus (GuzmánCornejo et al. 2016). Specimens in collections: CNAC 002159 (Canis), CNAC 002240 (Lynx).

Haemaphysalis leporispalustris Packard, 1869

SINALOA: Canis lupus familiaris (Sosa-Gutiérrez et al. 2016a). No specimens in collections.

\section{Ixodes affinis Neumann, 1899}

YUCATÁN: Mayapan [listed as Municipio in the literature]: Felis catus (Peniche-Lara et al. 2018). Calotmul, Muna, Tekax, and Ticul [listed as Municipios in the literature]: Canis lupus familiaris (Rodríguez-Vivas et al. 2016). Merida [listed as Municipio in the literature]: F. catus (Rodríguez-Vivas et al. 2016). No specimens in collections. Note: Tick described as "near affinis" in Rodríquez-Vivas et al. (2016). See also Kohls and Rogers (1953).

\section{Ixodes boliviensis Neumann, 1904}

CHIAPAS: Planta de Luz; Huixtla: Canis lupus familiaris (Hoffmann 1962, Hoffmann and López-Campos 2000, Guzmán-Cornejo et al. 2007a). Specimens in collections: CNAC 002165. GUERRERO: Atoyac: Panthera onca (Neumann 1906, Hoffmann 1962, Hoffmann and López-Campos 2000, Guzmán-Cornejo et al. 2007a). Specimens in collections: NTC. Note: Little is known about Neumann's collection at the NTC. OAXACA: San Antonio Otate: C. I. familiaris
(USNTC). Specimens in collections: USNTC (RML28411). Teotila; Cuicatlán; Yaviche: C. I. familiaris (Hoffmann 1962, Hoffmann and López-Campos 2000). Specimens in collections: Unknown; Hoffmann collection is in the CNAC. QUINTANA ROO: Bacalar: "fox" (Hoffmann 1962, Hoffmann and LópezCampos 2000, Guzmán-Cornejo et al. 2007a). Specimens in collections: Unknown; Hoffmann collection is in the CNAC.

Ixodes cookei Packard, 1869

VERACRUZ: Área Natural Protegida San Juan del Monte, 3.2 km SW, Las Vigas de Ramírez: Urocyon cinereoargenteus (Guzmán-Cornejo et al. 2007a, Montiel-Parra et al. 2007). Specimens in collections: CNAC.

Ixodes pacificus Cooley and Kohls, 1943

BAJA CALIFORNIA or BAJA CALIFORNIA SUR: Canis lupus familiaris (Hoffmann and López-Campos 2000). Specimens in collections: Unknown; Hoffmann collection is in the CNAC.

\section{Ixodes rubidus Neumann, 1901}

GUERRERO: Omiltemi: Urocyon cinereoargenteus (Hoffmann 1962, Guzmán-Cornejo et al. 2007a). Specimens in collections: CNAC 002364.

\section{Ixodes scapularis Say, 1821}

SINALOA: Canis lupus familiaris (Sosa-Gutiérrez et al. 2016a). No specimens in collections. TAMAULIPAS: Tampico: C. I. familiaris (Guzmán-Cornejo et al. 2007a). Reserva de Biosfera de El Cielo: Panthera onca (Almazán et al. 2013). Specimens in collections: CNAC 006803-006805 (ex. P. onca). NOT DETERMINED: C. I. familiaris, Leopardus pardalis (Macías-Valadez 1923, Hoffmann 1962, Whitaker and Morales-Malacara 2005). Specimens in collections: Unknown; Hoffmann collection is in the CNAC.

\section{Ixodes sp.}

QUERÉTARO: Parque Nacional El Cimatario: Urocyon cinereoargenteus (Hernández-Camacho et al. 2016). Specimens in collections: SIPHO.

\section{Rhipicephalus (Boophilus) annulatus Say, 1821}

NUEVO LEÓN: Benito Juárez: Canis lupus familiaris (Galaviz-Silva et al. 2013). No specimens in collections. SONORA: Cocorito: C. I. familiaris (Hoffmann 1962). Specimens in collections: Unknown; Hoffmann collection is in the CNAC.

Rhipicephalus (Boophilus) microplus (Canestrini, 1887)

SAN LUIS POTOSÍ: Tamazunchale: Canis lupus familiaris (Hoffmann 1962). Specimens in collections: Unknown; Hoffmann collection is in the CNAC. SINALOA: $11 \mathrm{~km}$ west of Escuinapa: Leopardus pardalis (USNTC). Specimens in 
collections: USNTC (RML50468). YUCATÁN: Tekom: L. pardalis (USNTC). Specimens in collections: USNTC (RML32132). UNKNOWN LOCALITY: C. I. familiaris (Hoffmann and LópezCampos 2000). Specimens in collections: Unknown; Hoffmann collection is in the CNAC.

\section{Rhipicephalus (Boophilus) sp.}

YUCATÁN: Chocholá, Hunucma, Chi Chi Suárez, Izamal, Muxupip, and Maxcanu [listed as "communities" in the literature]: Canis lupus familiaris (Zavala-Velázquez et al. 2002). No specimens in collections.

Rhipicephalus sanguineus (Latreille, 1806)

BAJA CALIFORNIA [SUR]: La Paz; San José del Cabo; Sierra de la Laguna; Todos Santos: Canis lupus familiaris (Hoffmann 1962). Specimens in collections: Unknown; Hoffmann collection is in the CNAC. CHIAPAS: Hamburgo; Mapastepec; Toralá: C. I. familiaris (Hoffmann 1962). Specimens in collections: Unknown; Hoffmann collection is in the CNAC. CHIHUAHUA: Juárez: C. I. familiaris (Hoffmann 1962). Specimens in collections: Unknown; Hoffmann collection is in the CNAC. COAHUILA: Monclova; Paras [Parras]; Sierra del Tlahualilo; Torreon: C. I. familiaris (USNTC). Specimens in collections: USNTC (RML23218, 58068, 58080, 60045). San José de Zaragoza: C. I. familiaris (Hoffmann 1962). Specimens in collections: Unknown; Hoffmann collection is in the CNAC. COLIMA: Colima: C. I. familiaris (Hoffmann 1962). Specimens in collections: Unknown; Hoffmann collection is in the CNAC. DURANGO: Lerdo, Tlahualilo: C. I. familiaris (USNTC). Specimens in collections: USNTC (RML60027, 60061). GUERRERO: Cocula; Iguala: C. I. familiaris (Hoffmann 1962). Specimens in collections: Unknown; Hoffmann collection is in the CNAC. JALISCO: Nazareno: C. I. familiaris (Hoffmann 1962). Specimens in collections: Unknown; Hoffmann collection is in the CNAC. MORELOS: Acatlipa: C. I. familiaris (USNTC). Specimens in collections: USNTC (RML33102). Cuernavaca: C. I. familiaris (Cruz-Vásquez and García-Vásquez 1999). No specimens in collections. NUEVO LEÓN: Monterrey: C. I. familiaris (Hoffmann 1962). Pesquería; Benito Juárez; Apodaca; Santiago; Estanzuela; Guadalupe; Monterrey; Escobedo; San Nicolás de los Garza: C. I. familiaris (Galaviz-Silva et al. 2013). Specimens in collections: Unknown; Hoffmann collection is in the CNAC. Monterrey: C. I. familiaris (USNTC). Specimens in collections: USNTC (RML58061). OAXACA: Ixtepec; Salina Cruz; Tehuantepec: C. I. familiaris (USNTC, Hoffmann 1962). Specimens in collections: USNTC (RML21198, 58054) and Unknown; Hoffmann collection is in the CNAC. Salina Cruz: Felis catus (Hoffmann 1962). Specimens in collections: Unknown; Hoffmann collection is in the CNAC. QUINTANA ROO: Cancun; Puerto Morelos: C. I. familiaris (USNTC). Specimens in collections: USNTC (RML64444, 66537). SAN LUIS POTOSÍ: Tamazunchale: C. I. familiaris (USNTC). Specimens in collections: USNTC (RML23795). Xilitla; [Ciudad] Valles: C. I. familiaris (Hoffmann 1962). Specimens in collections: Unknown; Hoffmann collection is in the CNAC. SINALOA: C. I. familiaris (Sosa-Gutiérrez et al. 2016a). Aguacalientes; Ballehuey; Chinobampo; El Fuerte; El Mahone; La Palma; MazatIan; Ocolomé; San Felipe; San Javier; Tabucahun: C. I. familiaris (Hoffmann 1962). Specimens in collections: Unknown; Hoffmann collection is in the CNAC. Los Pozos: C. I. familiaris (USNTC). Specimens in collections: USNTC (RML14000). SONORA: Alamas; Esperanza; La Dura; La Gloria; Tomichi: C. I. familiaris (Hoffmann 1962). Specimens in collections: Unknown; Hoffmann collection is in the CNAC. TAMAULIPAS: [Ciudad] Victoria: C. I. familiaris (Roberts 1934). Tampico: C. I. familiaris (Hoffmann 1962). Specimens in collections: Unknown; Hoffmann collection is in the CNAC. Comales, 20 miles SW of Nuevo Laredo: C. I. familiaris (USNTC). Specimens in collections: USNTC (RML21781, 23444, 23794). VERACRUZ: Cosamaloapan: C. I. familiaris (Hoffmann 1962). Specimens in collections: Unknown; Hoffmann collection is in the CNAC. YUCATÁN: Progresso, Santa Maria: C. I. familiaris, F. catus (Hoffmann 1962). Mayapan [listed as Municipio in the literature]: C. I. familiaris (Peniche-Lara et al. 2018). Mérida: C. I. familiaris (Pat-Nah et al. 2015). Mérida, Valladolid, Motul, Muna, Ticul, Tizimín, Calotmul, Panaba, Peto [listed as Municipios in the literature]: C. I. familiaris (Rodríguez-Vivas et al. 2016, 2017a, 2017b). Chocholá, Hunucma, Dzununcan, Chi Chi Suarez, Dzalbay, Izamal, Maxcanu, Rio Lagartos [listed as 'communities' in the literature]: C. I. familiaris (ZavalaVelázquez et al. 2002). Specimens in collections: Unknown; Hoffmann collection is in the CNAC. UNKNOWN LOCALITY: C. I. familiaris (Hoffmann and López-Campos 2000). Puma concolor (Hoffmann 1962). Panthera onca (Hoffmann 1962, Whitaker and Morales-Malacara 2005). Specimens in collections: Unknown; Hoffmann collection is in the CNAC.

Rhipicephalus sp.

SINALOA: C. I. familiaris (Sosa-Gutiérrez et al. 2016a). No specimens in collections.

Phylum: Arthropoda von Siebold, 1848

Class: Arachnida Lamarck, 1801

Subclass: Acari Leach, 1817

Superorder: Parasitiformes Leach, 1815

Order: Sarcoptiformes Reuter, 1909

Family: Demodicidae Nicolet, 1855

Demodex canis Leydig, 1859

YUCATÁN: Mérida: Canis lupus familiaris (RodriguezVivas et al. 2003). No specimens in collections. UNKNOWN LOCALITY: C. I. familiaris (Hoffmann and López-Campos 2000). Specimens in collections: Unknown; Hoffmann collection is in the CNAC.

\section{Demodex cati Megnin, 1877}

UNKNOWN LOCALITY: Felis catus (Hoffmann and LópezCampos 2000). Specimens in collections: Unknown; Hoffmann collection is in the CNAC. 
Psoroptidae Canestrini, 1892

Otodectes cynotis (Hering, 1838)

YUCATÁN: Mérida: Canis lupus familiaris (RodriguezVivas et al. 2003). No specimens in collections.

\section{Sarcoptidae Murray, 1877 \\ Sarcoptes scabiei var. canis}

YUCATÁN: Mérida: Canis lupus familiaris (RodriguezVivas et al. 2003). No specimens in collections. UNKNOWN LOCALITY: C. I. familiaris (Hoffmann and López-Campos 2000). Specimens in collections: Unknown; Hoffmann collection is in the CNAC.

Notoedres cati (Hering, 1838)

UNKNOWN LOCALITY: Felis catus (Hoffmann and LópezCampos 2000). Specimens in collections: Unknown; Hoffmann collection is in the CNAC.

Phylum: Arthropoda von Siebold, 1848

Class: Insecta Linnaeus, 1758

Order: Phthiraptera Haekel, 1896

Suborder: Ischnocera Kellogg, 1896a

Family: Trichodectidae Kellogg, 1896a

Bovicola caprae (Gurlt, 1843)

COAHUILA: Arteaga: Canis lupus familiaris (SánchezMontes et al. 2018). Note: This record likely represents accidental contamination. No specimens in collections.

\section{Trichodectes canis (De Geer, 1778)}

TABASCO: Ignacio Gutierrez Gómez Cárdenas: Canis lupus familiaris (Torres-Chable et al. 2017, Sánchez-Montes et al. 2018). No specimens in collections. YUCATÁN: Mayapan [listed as Municipio in the literature]: C. I. familiaris (Peniche-Lara et al. 2018). No specimens in collections.

Amblycera Kellogg, 1896a

Boopiidae Mjöberg, 1910

Heterodoxus spiniger (Enderlein, 1909)

CIUDAD DE MÉXICO: Reserva Ecológia del Pedregal de San Ángel: Canis lupus familiaris (Pacheco-Coronel 2010, Sánchez-Montes et al. 2018). Unknown if specimens are in collections. COAHUILA: C. I. familiaris (Lozoya-Saldaña et al. 1986, Sánchez-Montes et al. 2018). Unknown if specimens are in collections. TABASCO: Ignacio Gutierrez Gomez Cárdenas; Ignacio Allende Centla; Villahermosa: C. I. familiaris (Torres-Chable et al. 2017, SánchezMontes et al. 2018). No specimens in collections.
Anoplura Leach, 1815

Polyplacidae Fahrenholz, 1912

Polyplax sp.

YUCATÁN: Chocholá, Hunucma, Muxupip [listed as "communities" in the literature]: Canis lupus familiaris (Zavala-Velázquez et al. 2002). No specimens in collections. Note: This is an unusual host association. Members of the sucking louse genus Polyplax are adapted as ectoparasites of rodents (Durden and Musser 1994).

Phylum: Arthropoda von Siebold, 1848

Class: Insecta Linnaeus, 1758

Order: Siphonaptera Latreille, 1825

Family: Pulicidae Billberg, 1820

Cediopsylla inaequalis interrupta Jordan, 1925

ESTADO DE MÉXICO: Popocatépetl: Lynx rufus (Barrera 1968). Specimens in collections: MZFC. MORELOS: Lagunas de Zempoala: L. rufus (Barrera 1954, Barrera 1968, AyalaBarajas et al. 1988). Specimens in collections: MZFC.

\section{Cediopsylla simplex (Baker, 1895)}

ESTADO DE MÉXICO: Popocatépetl: Lynx rufus (Barrera 1968). Specimens in collections: MZFC. GUERRERO: Chilpancingo de los Bravos: Urocyon cinereoargenteus (Acosta et al. 2008). Specimens in collections: MZFC. MORELOS: Lagunas de Zempoala, 1 km NE de la Laguna: L. rufus (Barrera 1954, Barrera 1968, Ayala-Barajas et al. 1988). Specimens in collections: MZFC.

\section{Ctenocephalides canis (Curtis, 1826)}

AGUASCALIENTES: Aguascalientes: Canis lupus familiaris (Hernández-Valdivia et al. 2011). No specimens in collections. CHIAPAS: Pueblo Nuevo: Urocyon cinereoargenteus (Hubbard 1958). Specimens in collections: Unknown; Possibly BMNH. CIUDAD DE MÉXICO: Tlalpan; San Andrés Totoltepec: C. I. familiaris (Acosta et al. 2008). C. I. familiaris (Barrera 1953). Specimens in collections: MZFC. Tacubaya: C. I. familiaris (Hopkins and Rothschild 1953). Specimens in collections: BMNH. GUANAJUATO: Irapuato-Salamanca: $C$. I. familiaris (Ortega-Palomares et al. 2014). No specimens in collections. GUERRERO: Camotla, Chichihulco [listed as Municipio in the literature]: C. I. familiaris (Ayala-Barajas et al. 1988). Specimens in collections: MZFC. HIDALGO: Tlanchinol: C. I. familiaris (Salceda-Sánchez and Hastriter 2006). Specimens in collections: CAIM, InDRE. MORELOS: Cuernavaca City: C. I. familiaris, Felis catus (Cruz-Vazquez et al. 2001). No specimens in collections. QUERÉTARO: Parque Nacional El Cimatario: Urocyon cinereoargenteus (Hernández-Camacho et al. 2016). Specimens in collections: SIPHO 8828, 8829. Querétaro: F. catus (Cantó et al. 2013). No specimens in collections. VERACRUZ: Zaragoza: C. I. familiaris 
(Salceda-Sánchez and Hastriter 2006). Specimens in collections: CAIM, InDRE.

Ctenocephalides felis (Bouché, 1835)

AGUASCALIENTES: Aguascalientes: Canis lupus familiaris (Hernández-Valdivia et al. 2011). No specimens in collections. CAMPECHE: Calakmul Biosphere Reserve: C. I. familiaris (Villalobos-Cuevas et al. 2016). No specimens in collections. CIUDAD DE MÉXICO: C. I. familiaris (Barrera 1953). Popocatépetl: Lynx rufus (Barrera 1968). Specimens in collections: MZFC. Pedregal de San Angel: C. I. familiaris. Cd. Universitaria: Felis catus (Machado-A. 1960). Unknown if specimens are in collections. ESTADO DE MÉXICO: Texcoco: F. catus (Barrera 1953). Specimens in collections: MZFC. HIDALGO: Tlanchinol: C. I. familiaris (Salceda-Sánchez and Hastriter 2006). Specimens in collections: CAIM, InDRE. MORELOS: Cuernavaca City: C. I. familiaris, F. catus (CruzVazquez et al. 2001). No specimens in collections. Lagunas de Zempoala, $1 \mathrm{~km}$ NE de la Laguna: L. rufus (Barrera 1954). Specimens in collections: MZFC. OAXACA: Temascal: Puma concolor (Ayala-Barajas et al. 1988). Specimens in collections: MZFC. PUEBLA: Chietla: Urocyon cinereoargenteus (Ayala-Barajas et al. 1988). Specimens in collections: MZFC. QUERÉTARO: Parque Nacional El Cimatario: Urocyon cinereoargenteus (Hernández-Camacho et al. 2016). Specimens in collections: SIPHO 8830, 8831. QUERÉTARO: $F$. catus (Cantó et al. 2013). No specimens in collections. Periurban zones: C. I. familiaris, U. cinereoargenteus (MorenoPérez et al. 2016). No specimens in collections. SINALOA: El Fuerte: F. catus (Ayala-Barajas et al. 1988). Specimens in collections: MZFC. VERACRUZ: Misantla: F. catus (Hopkins and Rothschild 1953). Specimens in collections: BMNH. YUCATÁN: Mayapan [listed as Municipio in the literature]: C. I. familiaris, F. catus (Peniche-Lara et al. 2018). Merida: C. I. familiaris, Felis catus (Eckerlin 2005). Chichen Itza: C. I. familiaris (Eckerlin 2005). Chocholá, Hunucma, Dzalbay, Izamal, Muxupip, Maxcanu, Progreso [listed as "communities" in the literature]: C. I. familiaris (Zavala-Velázquez et al. 2002). No specimens in collections.

\section{Echidnophaga gallinacea (Westwood, 1875)}

CHIHUAHUA: Janos Biosphere Reserve: Canis latrans, Lynx rufus, Urocyon cinereoargenteus, Vulpes macrotis (LópezPérez et al. 2018). No specimens in collections. ESTADO DE MÉXICO: Texcoco: L. rufus (Ayala-Barajas et al. 1988). Specimens in collections: MZFC. QUERÉTARO: Parque Nacional El Cimatario: U. cinereoargenteus (Hernández-Camacho et al. 2016). Specimens in collections: SIPHO 8825, 8826. Querétaro: Felis catus (Cantó et al. 2013). No specimens in collections. SINALOA: El Fuerte: F. catus (Ayala-Barajas et al. 1988). Specimens in collections: MZFC. SONORA: Arroyo la Jabalina, Rancho Noche Buena, 30 km NNO Guaymas: C. latrans (Ayala-Barajas et al. 1988). Specimens in collections: MZFC.
Euhoplopsyllus glacialis affinis (Baker, 1904)

CHIHUAHUA: Janos Biosphere Reserve: Urocyon cinereoargenteus (López-Pérez et al. 2018). No specimens in collections. QUERÉTARO: Parque Nacional El Cimatario: U. cinereoargenteus (Hernández-Camacho et al. 2016). Specimens in collections: SIPHO 8824.

Pulex (Juxtapulex) echidnophagoides (Wagner, 1933)

QUINTANA ROO: PUEBLA Nuevo: Puma concolor (Eckerlin 2005). Specimens in collections: CMNH B63937. Note: Eckerlin (2005) indicates that this may be an incorrect host association.

\section{Pulex irritans Linnaeus, 1758}

CHIAPAS: Pueblo Nuevo: Urocyon cinereoargenteus (Hubbard 1958). Specimens in collections: BMNH. CHIHUAHUA: Janos Biosphere Reserve: Canis latrans, Vulpes macrotis (López-Pérez et al. 2018). No specimens in collections. CIUDAD DE MÉXICO: C. Iupus familiaris (Barrera 1953, Ayala-Barajas et al. 1988). Cerro San Miguel: C. latrans (Barrera 1953, Barrera 1955a). Specimens in collections: MZFC. MORELOS: Huitzilac [listed as Municipio in the literature]; Lagunas de Zempoala, $1 \mathrm{~km}$ NE de la Laguna: Lynx rufus (Barrera 1954). Specimens in collections: MZFC. OAXACA: Oaxaca: Felis catus (Barrera 1955a). Specimens in collections: MZFC. QUERÉTARO: Querétaro: F. catus (Cantó et al. 2013). No specimens in collections.

Pulex porcinus Jordan and Rothschild, 1923

CAMPECHE: 51 km E Escarcega: Panthera onca (Eckerlin 2005). Specimens in collections: CMNH B57317. Cakamul Biosphere Reserve: Urocyon cinereoargenteus (VillalobosCuevas et al. 2016). No specimens in collections. QUINTANA ROO: Pueblo Nuevo: Puma concolor (Eckerlin 2005). Specimens in collections: CMNH B63941. TAMAULIPAS: Santander de Jiménez: Panthera onca (Barrera 1955a, Barrera 1955b, Ayala-Barajas et al. 1988). Specimens in collections: MZFC.

\section{Pulex simulans Baker, 1895}

BAJA CALIFORNIA [SUR]: La Laguna: Canis lupus familiaris (Ayala-Barajas et al. 1988). Specimens in collections: MZFC. CHIHUAHUA: Janos Biosphere Reserve: C. latrans, Lynx rufus, Urocyon cinereoargenteus, Vulpes macrotis (López-Pérez et al. 2018). No specimens in collections. CIUDAD DE MÉXICO: Cerro San Miguel, Contreras: C. latrans (Ayala-Barajas et al. 1988). Specimens in collections: MZFC. ESTADO DE MÉXICO: Popocatépetl: C. latrans (Barrera 1968). Specimens in collections: MZFC. HIDALGO: Tlanchinol: C. I. familiaris (Salceda-Sánchez and Hastriter 2006). Specimens in collections: CAIM, InDRE. JALISCO: La Unión de San Antonio, $30 \mathrm{~km}$ de Lagos de Moreno: C. latrans (Ayala-Barajas et al. 1988). Specimens in collections: MZFC. MORELOS: Lagunas de Zempoala: L. rufus (Barrera 1955a). Specimens in collections: MZFC. OAXACA: Oaxaca: F. catus (Ayala-Barajas 
et al. 1988). Specimens in collections: MZFC. PUEBLA: Chietla: U. cinereoargenteus (Ayala-Barajas et al. 1988). Specimens in collections: MZFC. QUERÉTARO: Parque Nacional El Cimatario: $U$. cinereoargenteus (Hernández-Camacho et al. 2016). Specimens in collections: SIPHO 8832. Periurban zones. C. I. familiaris, U. cinereoargenteus (Moreno-Pérez et al. 2016). No specimens in collections. SAN LUIS POTOSí: Guaname: C. latrans (Ayala-Barajas et al. 1988). Specimens in collections: MZFC. SINALOA: Rancho la Culebra: C. latrans (Barrera 1955a, Ayala-Barajas et al. 1988). Specimens in collections: MZFC. SONORA: Los Fresnos: U. cinereoargenteus (Zapata-Valdés et al. 2018). No specimens in collections. Arroyo de Jabalina, Rancho Noche Buena, 30 km NNO de Guaymas: C. latrans (Ayala-Barajas et al. 1988). Specimens in collections: MZFC. ZACATECAS: Rancho el Fresno, 20 km al S de Pinos: Urocyon sp. (Ayala-Barajas et al. 1988). Specimens in collections: MZFC.

\section{Pulex sp.}

CHIHUAHUA: Janos Biosphere Reserve: Canis latrans, Urocyon cinereoargenteus, Vulpes macrotis (López-Pérez et al. 2018). No specimens in collections. ZACATECAS: Rancho el Fresno, 20 km al S de Pinos: Urocyon sp. (Ayala-Barajas et al. 1988). Specimens in collections: MZFC.

\section{Xenopsylla cheopis (Rothschild, 1903)}

NUEVO LEÓN: Mendivil: C. I. familiaris (Salceda-Sánchez and Hastriter 2006). Specimens in collections: CAIM, InDRE. VERACRUZ: Misantla: Felis catus (Hopkins and Rothschild 1953). Specimens in collections: BMNH.

Rhopalopsyllidae Oudemans, 1909

Rhopalopsyllus australis (Rothschild, 1904)

CAMPECHE: Cakamul Biosphere Reserve: Urocyon cinereoargenteus (Villalobos-Cuevas et al. 2016). No specimens in collections. OAXACA: Temascal: Puma concolor (AyalaBarajas et al. 1988). Specimens in collections: MZFC.

Rhopalopsyllus saevus Jordan and Rothchild, 1923

CAMPECHE: Cakamul Biosphere Reserve: Herpailurus yagouaroundi, Leopardus pardalis (Villalobos-Cuevas et al. 2016). No specimens in collections.

\section{Ceratophyllidae Dampf, 1908 \\ Orchopeas howardi (Baker, 1895)}

CHIAPAS: Pueblo Nuevo: Urocyon cinereoargenteus (Hubbard 1958). Specimens in collections: Unknown; Possibly BMNH.

\section{Orchopeas sexdentatus (Baker, 1904)}

CHIHUAHUA: Janos Biosphere Reserve: Canis latrans (López-Pérez et al. 2018). No specimens in collections.
Thrassis aridis Prince, 1944

CHIHUAHUA: Janos Biosphere Reserve: Lynx rufus (López-Pérez et al. 2018). No specimens in collections.

\section{Acknowledgments}

We thank J. A. Fernández for providing this opportunity to publish this checklist, and for helping with the Spanish translation and online access to Therya. A. Camargo Sanabria and $\mathrm{H}$. Fontes provided help with references and helped to search for mite records. Reviews from three anonymous reviews helped to improve the quality of this checklist. This is publication 1602 of the Biodiversity Research and Teaching Collections at Texas A\&M University.

\section{Literature cited}

Acosta, R., J. A. Fernández, J. Llorente, and M. C. Jiménez. 2008. Catálogo de Pulgas (Insecta: Siphonaptera). Serie de Catálogos del Museo de Zoología "Alfonso L. Herrera" UNAM, Las Prensas de Ciencias, Ciudad de México, México.

Almazán, C., I. Castro-Arellano, and E. Camacho-Puga. 2013. Blacklegged ticks (Ixodes scapularis) on the jaguar (Panthera onca). The Southwestern Naturalist 58:122-124.

Ayala-Barajas, R., J. C. Morales, N. Wilson, J. E. Llorente, and H. E. PonCE. 1988. Catálogo de las pulgas (Insecta: Siphonaptera). Serie de Catálogos del Museo de Zoología "Alfonso L. Herrera"UNAM. Facultad de Ciencias. 1: Colección Alfredo Barrera 1:1-102.

Barnes, A. M., V. J. Tipton, And J. A. Wilde. 1977. The subfamily Anomiopsyllinae (Hystrichopsyllidae: Siphonaptera). I. A revision of the genus Anomiopsyllus Baker. Great Basin Naturalist 37:138-206.

Barrera, A. 1953. Sinopsis de los sifonápteros de la Cuenca de México (Ins., Siph.). Anales de la Escuela Nacional de Ciencias Biológicas 7:155-245.

Barrera, A. 1954. Notas sobre sifonápteros. VII. Lista de especies colectades en el Municipio de Huitzilac, Morelos, y descripción de Peromyscopsylla zempoalensis nov. sp (Siph. Leptos.). Ciencia México 14:87-90.

Barrera, A. 1955a. Las especies mexicanas del género Pulex Linnaeus (Siph., Pulicid). Anales de la Escuela Nacional de Ciencias Biológicas 8:219-236.

Barrera, A. 1955b. Notas sobre Siphonápteros. I. Algunas especies mexicanas: consideracions sobre su distribución geográfica. Revista de la Sociedad Mexicana de Entomología 1:85-98.

Barrera, A. 1968. Distribución cliserial de los Siphonaptera del volcán Popocatépetl, su interpretción biogeográfica. Anales del Instituto de Biología, Universidad Nacional Autónoma de México 39:35-100.

Beatl, L., S. Nava, E. J. Burkman, D. M. Barros-Battestı, M. B. Labruna, A. A. Guglielmone, A. G. Cáceres, C. M. Guzmán-Cornejo, R. León, L. A. Durden, and J. L. H. Faccinı. 2013. Amblyomma cajennense (Fabricius, 1787) (Acari: Ixodidae), the Cayanne tick: phylogeography and evidence for allopatric speciation. BMC Evolutionary Biology 13:267.

Burgin, C. J., J. P. Colella, P. L. Kahn, and N. S. Upham. 2018. How many species of mammals are there? Journal of Mammalogy 99:1-14. 
Cantó, G. J., R. I. Guerrero, A. M. Olvera-Ramírez, F. Milián, J. Mosqueda, and G. Aguilar-Tipacamú. 2013. Prevalence of fleas and gastrointestinal parasites in free-roaming cats in Central Mexico. PLoS One 8:e60744.

Chavarría, C. M. 1941. Garrapatas determinadas en México. Caracteres genéricos de las más comunes. Revista del Instituto-Pecuario 1:18-24.

Cook, J. A., S. Greiman, S. Agosta, R. P. Anderson, B. S. Arbogast, R. J. Baker, W. Boeger, R. D. Bradley, D. R. Brooks, R. Cole, J. R. Demboski, A. P. Dobson, J. L. Dunnum, R. P. Eckerlin, J. Esselstyn, K. Galbreath, J. Hawdon, H. Hoekstra, S. Kutz, J. E. Light, L. Olson, B. D. Patterson, J. L. Patton, A. J. Phillips, E. Rickart, D. S. Rogers, M. E. Siddall, V. TKaCh, and E. P. Hoberg. 2016. Transformational principles for NEON sampling of mammalian parasites and pathogens: a response to Springer and colleagues. BioScience 66:917-919.

Cook, J. A., K. E. Galbreath, K. C. Bell, M. L. Campbell, S. Carrière, J. P. Colella, N. G. Dawson, J. L. Dunnum, R. P. Eckerlin, S. E. Greiman, V. Fedorov, G. M. S. Hass, V. Haukisalmi, H. Henttonen, A. G. Hope, D. Jackson, T. Jung, A. V. Koehler, M. Kinsella, D. Krejsa, S. J. Kutz, S. Liphardt, S. O. MacDonald, J. L. Malaney, A. Makarikov, J. Martin, B. S. Mclean, R. Mulders, B. Nyamsuren, S. L. Talbot, V. V. TKach, A. Tsvetkova, H. M. Toman, E. C. Waltari, J. L. Whitman, and E. P. HoBERG. 2017. The Beringian coevolution project: Holistic collections of mammals and associated parasites reveal novel perspectives on evolutionary and environmental change in the north. Arctic Science 3:585-617.

Cook, J. A. AND J. E. LIGHT. 2019. The emerging role of mammal collections in 21st century mammalogy. Journal of Mammalogy 100:733-750.

Cooley, R. A., AND G. M. Kohls. 1945. The genus Ixodes in North America. National Institutes of Health Bulletin 184:1-246.

Cruz-Vazquez, C., E. C. Gamez, M. P. Fernandez, and M. R. Parra. 2001. Seasonal occurrence of Ctenocephalides felis felis and Ctenocephalides canis (Siphonaptera: Pulicidae) infesting dogs and cats in an urban area in Cuernavaca, Mexico. Journal of Medical Entomology 38:111-113.

Cruz-Vasquez, C., and Z. Garcia-Vasquez. 1999. Seasonal distribution of Rhipicephalus sanguineus ticks (Acara: Ixodidae) on dogs in an urban area of Morelos, Mexico. Experimental and Applied Acarology 23:277-280.

DAvIS, G. E. 1943. Studies on the biology of the argasid tick, Ornithodoros nicollei Mooser. Journal of Parasitology 20:393-395.

Durden, L. A., AND G. G. Musser. 1994. The sucking lice (Insecta, Anoplura) of the world: a taxonomic checklist with records of mammalian hosts and geographical distributions. Bulletin of thee American Museum of Natural History 218:1-90.

ECKerlin, R. P. 2005. Fleas (Siphonaptera) of the Yucatan Peninsula (Campeche, Quintana Roo, and Yucatan), Mexico. Caribbean Journal of Science 41:52-57.

Galaviz-Silva, L., K. C. Pérez-Treviño, and Z. J. Molina-Garza. 2013. Distribution of ixodid ticks on dogs in Nuevo León, Mexico, and their association with Borrelia burgdorferi sensu lato. Experimental and Applied Acarology 61:491-501.

Gordillo-Pérez, G., M. Vargas, F. Solorzano-Santos, A. Rivera, O. J. Polaco, L. Alvarado, O. Muñoz, and J. Torres. 2009. Demonstration of Borrelia burgdorferi sensu stricto infection in ticks from the northeast of Mexico. Clinical Microbiology and Infectious Diseases 15:496-498.
Guzmán-Cornejo, C., R. G. Robbins, A. A. Guglielmone, G. MontielParra, And T. M. Pérez. 2011. The Amblyomma (Acari, Ixodida, Ixodidae) of Mexico: identification keys, distribution and hosts. Zootaxa 2998:16-38.

Guzmán-Cornejo, C., R. G. Robbins, A. A. Guglielmone, G. MontielParra, G. Rivas, and T. M. Pérez. 2016. The Dermacentor (Acari, Ixodida, Ixodidae) of Mexico: hosts, geographical distribution and new records. Zookeys 569:1-22.

Guzmán-Cornejo, C., R. G. Robbins, and T. M. Pérez. 2007a. The Ixodes (Acari : Ixodidae) of Mexico: parasite-host and hostparasite checklists. Zootaxa 1553:47-58.

Guzmán-Cornejo, C., R. G. Robbins, A. A. Guglielmone, G. MontielParra, And T. M. Pérez. 2007b. The Amblyomma (Acari: Ixodida: Ixodidae) of Mexico: Identification keys, distribution and hosts. Zootaxa 2998:16-38.

Hernández-Camacho, N., R. F. Pineda-López, M. D. Guerrero-Carrillo, G. J. Cantó-Alarcón, R.W. Jones, M. A. Moreno-Pérez, J. J. MosquedaGualito, S. Zamora-Ledesma, and B. Camacho-Macías. 2016. Gray fox (Urocyon cinereoargenteus) parasite diversity in central Mexico. International Journal of Parasitology-Parasites and Wildlife 5:207-210.

Hernández-Valdivia, E., C. Cruz-Vázquez, R. Ortiz-Martínez, A. Valdivia-Flores, and M. T Quintero-Martínez. 2011. Presence of Ctenocephalides canis (Curtis) and Ctenocephalidea felis (Bouché) infesting dogs in the city of Aguascalientes, Mexico. Journal of Parasitology 97:1017-1019.

Hoffmann, A. 1961. Artrópodos mexicanos de interés médico y veterinario. Productes DDT, S. A. Ciudad de México, México.

Hoffmann, A. 1962. Monografía de los Ixodoidea de México. I parte. Revista de la Sociedad Mexicana de Historia Natural 23:191-307.

Hoffmann, A., I. Bassols, and C. Méndez. 1972. Nuevos hallazgos de ácaros en México. Revista de la Sociedad Mexicana de Historia Natural 33:151-159.

Hoffmann, A., and G. López-Campos. 2000. Biodiversidad de los ácaros en México. Comisión Nacional para el Conocimiento y Uso de la Biodiversidad, Universidad Nacional Autónoma de México. Ciudad de México, México.

Hoffmann, C. C. 1925. La fiebre manchada de Choix. Memoria preliminar. Boletín del Departamento de Salubridad Pública 1:33-37.

HopkINS, G. H. E., AND M. RothSCHILD. 1953. An illustrated catalogue of the Rothschild collection of fleas (Siphonaptera) in the British Museum (Natural History) with keys and short descriptions for the identification of families, genera, species and subspecies. Volume I. Tungidae and Pulicidae. British Museum (Natural History). London, UK.

Hopkins, G. H. E., AND M. RothsCHILD. 1966. An Illustrated Catalogue of the Rothschild Collection of Fleas (Siphonaptera) in the British Museum (Nat. Hist.). Vol. 4. Hystrichopsyllidae. British Museum (Natural History). London, UK.

HubBard, C. A. 1958. Mexican jungle and desert fleas with three new descriptions. Entomological News 69:161-168.

Kohls, G. M., And C. M. Clifford. 1966. Three new species of Ixodes from Mexico and description of the male of $I\left(I_{.}\right)$ auritulus Neumann, I. conepati Cooley and Kohls, and I. Iasallei Mendez and Ortis (Acarina: Ixodidae). Journal of Parasitology 52:810-820. 
Kohls, G. M., AND A. J. Rogers. 1953. Note on the occurrence of the tick Ixodes affinis Neumann in the United States. Journal of Parasitology 39:669.

López-Pérez, A. M., K. Gage, A. V. Rubio, J. Montenierl, L. Orozco, and G. SuzAN. 2018. Drivers of flea (Siphonaptera) community structure in sympatric wild carnivores in northwestern Mexico. Journal of Vector Ecology 43:15-25.

Lozoya-Saldaña, A., S. Quinones-Luna, L. A. Aguirre-Uribe, and E. Guerrero-Rodríguez. 1986. Distribución y abundancia de los piojos malófagos y anopluros del Ganado ovino y caprino en la region de Saltillo, Coahuila, Mexico. Folia Entomológia Mexicana 69:117-125.

MACHAdO-A. C. E. 1960. Microtus mexicanus mexicanus (De Santssate, 1861) Su biologia ectoparasitos y otras formas animals ecológicamente relacionadas. Tesis professional, Facultad de Ciencias, UNAM.

Macías VAlADEZ, S. 1923. Ensayo de una monografía sobre Ixodidos mexicanos vulgo garrapatos. Memorias de la Sociedad Cientifica Antonio Alzate 41:197-216.

Montiel-Parra, G., H. Fuentes-Moreno, and M. Vargas. 2007. Primer registro de Ixodes cookei (Acari: Ixodidae) para México. Revista Mexicana de Biodiversidad 78:205-206.

Morales, J. C., And J. Llorente. 1986. Estado actual del conocimiento de los Siphonaptera de México. Anales del Instituto de Biología, UNAM, Serie Zoología 2:497-554.

Morales-Muciño, J. C., AND J. Llorente-Bousquets. 1985. Estado actual del conocimiento de los Siphonaptera de Mexico. Anales del Instituto de Biología, UNAM, Serie Zoología 56:497-554.

Moreno-Pérez, M. A., N Hernández-Camacho, R. Acosta-Gutiérrez, C. Guzmán-Cornejo, R. Pineda-López, R. W. Jones, S. VergaraPineda, S. Zamora-Ledezma, and B. Camacho-Macías. 2016. Diversidad de artrópodos ectoparásitos en zorra gris (Urocyon cinereoargenteus) y perros peridomésticos en áreas suburbanas del estado de Querétaro. in Memorias del XIII Congreso Nacional de Mastozoología (Carrillo-Reyes, A., and T. M. Rioja-Paradela, eds.). Chiapas, México.

Muñiz, A. M., J. C. Morales-M., R. Ayalá-Barajas, and J. LlorenteBousquets. 1981. Primera lista de tipos depositados en el Museum de Zoología "Alfonso L. Herrera" de la Facultad de Ciencias de la Universidad Autónoma de México: Colleción de insectos ectoparásitos "Alfredo Barrera". Folia Entomológica Méxicana 49:155-168.

Nava, S. L. Beati, J. Dunlop, and A.A. Guglielmone. 2014 a. Reestablishment of Amblyomma tenellum Koch, 1844 (Acari: Ixodidae). Ticks and Tick-borne Diseases 5:620-623.

Nava, S. L. Beati, M.B. Labruna, A.G. Cáceres, A.J. Mangold, and A.A. Guglielmone. 2014b. Reassessment of the taxonomic status of Amblyomma cajennese (Fabricius, 1787) with a description of three new species, Amblyomma tonelliae n. sp., Amblyomma interandinum n. sp. and Amblyomma patinoi n. sp., and reinstatement of Amblyomma mixtum Koch, 1844, and Amblyomma sculptum Berlese, 1888 (Ixodida: Ixodide). Ticks and Tick-borne Diseases 5:252-276.

Neumann, L. G. 1906. Notes sur les Ixodidés. IV. Archives de Parasitologie 10:195-219.

Ortega-Palomares, J. E., H. G. Nuñez-Palenius, A. M. Cruz-Avalos, A. A. Hernández-Rangel, R. Lezama-Gutiérrez and C. A. Angel-Sahagún. 2014. Ocurrence of entomopathogenic fungus from flea
Ctenocephalides canis (Siphonaptera: Pulicidae). Open Journal of Veterinary Medicine 4:281-285.

PACheco-Coronel, N. 2010. Estudio piloto de la frecuencia de parásitos en mamíferos ferales y silvestres en la Reserva Ecológica del Pedregal de San Ángel de la UNAM. M. Sc. Thesis. Facultad de Medicina Veterinaria y Zootecnia, Universidad Nacional Autónoma de México. Coyoacán, México.

Pat-Nah, H., R. I. Rodriguez-Vivas, M. E. Bolio-Gonzalez, S. L. Villegas-Perez, and E. Reyes-Novelo. 2015. Molecular diagnosis of Ehrlichia canis in dogs and ticks Rhipicephalus sanguineus (Acari: Ixodidae) in Yucatan, Mexico. Journal of Medical Entomology 52:101-104.

Peniche-Lara, G., B. Jimenez-Delgadillo, C. Munoz-Zanzi, M. CárdenasMarrufo, C. Pérez-Osorio, and J. Arias-Leon. 2018. Presence of Rickettsia species in a marginalized area of Yucatan, Mexico. Journal of Tropical Medicine 7675828 10.1155/2018/7675828. Ponce Ulloa, H. E. and J.E. Llorente Bosquets. 1996. Siphonaptera. Pp. 553-565 in Biodiversidad, Taxonomia, y Biogeografia de Artropodos de Mexico: hacia una síntsis de su conocimiento (J. Llorente Bousquets, A. N. García Aldrete, and E. González Soriano, eds.). México: Universidad Nacional Autónoma de México, Instituto de Biología. Coyoacán, México.

Roberts, R. 1934. Some insects collected in Mexico, mostly in association with man and animals or animal products. Journal of the New York Entomological Society 42:249-262.

Rodríguez-Vivas, R. I., D. A. ApanaskeVich, M. M. OJeda-ChI, I. TrinidadMartínez, E. Reyes-Novelo, M. D. Esteve-Gassent, and A. A. Pérez de LEÓN. 2016. Ticks collected from humans, domestic animals, and wildlife in Yucatan, Mexico. Veterinary Parasitology 215:106-113.

Rodríguez-Vivas, R. I., M. M. OJeda-ChI, I. Trinidad-Martinez, AND M. E. Bolıo-GonzÁlez. 2017a. First report of amitraz and cypermethrin resistance in Rhipicephalus sanguineus sensu lato infesting dogs in Mexico. Medical and Veterinary Entomology 31:72-77.

Rodríguez-Vivas, R. I., M. M. Ojeda-Chi, I. Trinidad-Martinez, and A. A. P. DE LEÓN. 2017b. First documentation of ivermectin resistance in Rhipicephalus sanguineus sensu lato (Acari: Ixodidae). Veterinary Parasitology 233:9-13.

Rodríguez-Vivas, R. I., A. Ortega-Pacheco, J. A. Rosado-Aguilar, and G. M. E. Bolıo. 2003. Factors affecting the prevalence of mangemite infestations in stray dogs of Yucatan, Mexico. Veterinary Parasitology 115:61-65.

Salceda-SÁnchez, B., and M. W. Hastriter. 2006. A list of the fleas (Siphonaptera) of Mexico with new host and distribution records. Zootaxa 1296:29-43.

Sánchez-Montes, S., P. Colunga-Salas, L. Álvarez-Castillo, C. GuzmánCornejo, and G. Montiel-Parra. 2018. Chewing lice (Insecta: Phthiraptera) associated with vertebrates in Mexico. Zootaxa 4372:1-109.

Sosa-Gutiérrez, C. G., T. Quintero-Martinez, M. Vargas-Sandoval, AND G. Gordillo-Pérez. 2016a. First phylogenetic analysis of Ehrlichia canis in dogs and ticks from Mexico. Preliminary study. Revista MVZ Cordoba 21:5569-5576.

Sosa-Gutiérrez, C. G., M. Vargas-Sandoval, J. Torres and G. GordilloPÉREZ. 2016b. Tick-borne rickettsial pathogens in questing ticks, removed from humans and animals in Mexico. Journal of Veterinary Science 17:353-370.

Torres-Chable, O. M., C. M. Baak-BaAk, C. V. Zaragoza-Vera, G. 
Arjona-Jimenez, L. G. Moreno-Perez, P. Medina-Perez, C. MachainWilliams, AND J. E. Garcia-Rejon. 2017. First report of chewing lice Heterodoxus spiniger (Enderlein, 1909) and Trichodectes canis (De Geer, 1778) on domestic dogs at Tabasco, Mexico. Southwestern Entomologist 42:409-417.

Tovar, R. M. 1944. Existencia del Dermacentor parumapertus Neumann, Amblyomma inornatum Banks y Amblyomma maculatum Koch en México. Revista del Instituto de Salubridad y Enfermedades Tropicales 25:293-295.

Villalobos-Cuevas, V. A., M. Weber, M. Lareschi, and R. Acosta. 2016. Fleas of small and medium-sized mammals from Calakmul, Campeche, Mexico and new locality records. Revista Mexicana de Biodiversidad 87:1372-1378.

WEBSTER, M.S. 2017. The extended specimen:emerging frontiers in collections-based ornithological research. Studies in Avian Biology. Press/Taylor \& Francis Group. Boca Raton, U. S. A.

Whitaker, J. O., JR., AND J. B. Morales-Malacara. 2005. Ectoparasites and other associates (ectodytes) of mammals of Mexico. Pp. 535-665 in Contribuciones Mastozoológicas en Homenaje a Bernado Villa. (Sánchez-Cordero, V., and R. A. Medellin, eds.). Instituto de Biología, UNAM and CONABIO, México.

Zapata-Valdés, C., R. Avila-Flores, K. Gage, J. Holmes, J. Montenierri, M. Kosor, AND G. SUZÁN. 2018. Mammalian hosts, vectors, and bacterial pathogens in communities with and without blacktailed prairie dogs (Cynomys ludovicianus) in northwestern Mexico. Journal of Wildlife Diseases 54:26-33.

Zavala-Velázquez, J. E., J. E. Zavala-Castro, I. Vado-Solís, J. A. Ruiz-Sosa, C. G. Moron, D. H. Bouyer, and D. H. Walker. 2002. Identification of Ctenocephalides felis fleas as a host of Rickettsia felis, the agent of a spotted fever rickettsiosis in Yucatán, Mexico. Vector-borne and Zoonotic Diseases 2:69-75.

Associated editor: Jesús Fernández

Submitted: March 5, 2018; Reviewed: March 25, 2019;

Accepted: April 21, 2019; Published on line:April 30, 2019. 
